\title{
Product packaging policies and their role in improving the promotional mix of commercial companies exhibiting in the sports market from The consumer's perspective
}

\author{
DR. Abdelrahman megahed
}

\section{Introduction to the research:}

The internationalization and globalization of Commercial business forced many companies to reconsider what contributes to their competitive advantage, and the difference can occur through new policies, for example innovative packaging in terms of distinctive design in terms of cover, stamp, text and shape of the packaging for a pair of sports shoes provided by the company ( ADIDAS), which has become the biggest brand in the sports products market, can change product perception and create a new market position. (Packforsk, 2001).

There is no doubt that the design of the upgraded packages affects the increase in sales. These impacts stem from changes in consumer values such as convenience and functionality, as well as environmental issues and safety and security factors, (Packaging Federation, 2004). For example, other influences come from the new requirements of print quality in packaging, so packaging has become an important promotional tool for many products in a competitive business and sports environment. (Banks, S. 1950), and this is consistent with the results of a study (Prendergast and Pitt, 1996), packaging packages should perform many functions and many research emphasize the promotional and marketing function and that the package provides convenience in handling and storing the product.

In order for the packaging to develop its functions appropriately, the design, graphics, and packaging size will be subject to market research conducted by the company and the company's position in the market (Ivañez Gimeno, 2000), and this is consistent with the results of the (Underwood, 2003) study, in that packaging policies are undoubtedly linked With strategic decisions for the promotional mix in commercial enterprises.

Packaging design has become an important factor in promoting different products in the commercial markets and in the sports field. As it can be considered an integral part of the product, since the packaging can contribute to delivering the benefits of the product to the consumer, in some cases it is necessary to use the product, and it may be the same product. (George, 2005)

From the consumer's perspective, packaging also plays a major role when purchasing products, since it is the first thing that the public sees 
before making the final purchase decision (Giovannetti, 1995). This importance has increased with the application of packaging-based selfservice sales systems to attract attention and cause purchase (Fantoni, 2003), which is why packaging is called the 'silent seller', because it informs us of the qualities and benefits that we will obtain if we consume a specific product (Giovannetti, 1995) This is consistent with a study (McNeal et al, 2003), a study in which packaging provides producers with the last opportunity to convince potential buyers before choosing a brand, therefore, all elements of packaging, including texts, colors, structure, images and people / characters must be combined to provide the consumer By visual negotiation of sales when purchasing a product Use it

Numerous studies indicate various product packaging functions related to the promotion process (Prendergast and Pitt, 1996). Which shows the increasing importance of product packaging as a promotional tool, through the use of new media, public relations and personal selling houses, but also the importance of purchasing decisions. (Underwood et al, 2001)

\section{Research problem:}

Packaging is an important trade in the industrial part of the world and becomes more important for promotional purposes in developing countries. The value of the global packaging market is estimated at 500 billion USD, equivalent to 1 to 2 percent of gross national product. (Packforsk, 2001)

Global packaging expenditures are estimated from 1998 to 2019, around 27 percent in Europe, 21 percent in North America and 16 percent in Japan. The rest of the world represents 36 percent.

Research recommendations related to packaging included a communicative and promotional role, such as (Underwood et al, 2001), (Bonn and Currie, 2000), (Lee et al, 2003), (Bo Rundh, 2005), (Garreston.et.al, 2005). (Ampuero, 2006), (Raghubir and Greenleaf, 2006), (Bo Rundh, 2009), where she recommended attention to the packaging component to achieve a competitive advantage for producing companies, attention to packaging to deliver the product to the consumer, packaging plays the role of the silent salesman in showing the benefits of the product To the consumer, the interest of commercial companies in all areas with the packaging component to increase sales, increase the market share in institutions in the commercial markets by paying attention to product packaging.

Through the above, the researcher is trying through this study to reach the main role that packaging plays in delivering the personality of the sporting product to the consumer, as the study aims to discover the role of product packaging policies in improving the promotional mix of commercial companies in the sports field. 


\section{Research Objective:}

The research aims to identify the role of product packaging policies in improving the promotional mix for commercial companies exhibiting in the sports market, through the following sub-goals:

1. Study the relationship between the product packaging policy axes and the promotional mix axes for sports commercial companies.

2. Clarify the relationship between the demographic variables of the sample and each of the product packaging policies and its axes, the promotional mix of sports commercial companies and its axes.

3. Disclosure of the nature of the specific differences Research in each of the product packaging policies and its axes, the promotional mix of sports commercial companies and its axes. By (age)

4. Knowing the differences between the sample searches in each of the product packaging policies and its axes, the promotional mix of sports commercial companies and its axes. According to (income level).

\section{Research hypotheses:}

1. There is a statistically significant correlation between the product packaging policies and its axes, the promotional mix of sports commercial companies and its axes.

2. There is a statistically significant correlation between the demographic variables of the sample and each of the product packaging policies and its axes, the promotional mix of sports commercial companies and its axes.

3. There are statistically significant differences between the averages of the research sample degrees in each of the product packaging policies and its axes, the promotional mix of sports commercial companies and its axes. By (age).

4. There is a statistically significant difference between the degrees of the research sample in all product packaging policies and its axes, the promotional mix of sports commercial companies and its axes. According to (income level).

\section{Search procedures:}

\section{The Method used:}

The researcher used the descriptive method and the survey method to suit the research nature.

\section{research community:}

Consumers of commercial companies products exhibiting in the sports field.

\section{The research sample:}

The exploratory sample, numbered (50) individuals from the consumers of commercial companies' products exhibiting in the sports 
field in the Egyptian Arabic Republic, was chosen randomly from outside the main research sample and representative of the research community, from $(2 / 12 / 2019)$, to $(25 / 12 / 2019)$.

The main sample of the research consisted of (409) consumers of commercial companies products exhibiting in the sports field from (3) commercial companies (Adidas-Nike-Buma) in (5) different governorates (Cairo - Minya - Dakahlia - Damietta - Alexandria), in the Egyptian Arabic Republic, ethical guidelines were adhered to while conducting the research and the field application of the research tools was finalized from (4/1/2020) to $(28 / 1 / 2020)$, as shown in Table (1):

Table (1) A numerical and relative statement of the sample

\begin{tabular}{c|c|c|c|c|c|c|c|c|c}
\hline \hline \multirow{2}{*}{$\mathbf{N}$} & \multirow{2}{*}{ Governorate } & \multicolumn{2}{|c|}{ ADIDAS } & \multicolumn{2}{c|}{ NIKE } & \multicolumn{2}{c|}{ BUMA } & \multicolumn{2}{c}{ Total } \\
\cline { 2 - 10 } & $\mathbf{N}$ & $\mathbf{\%}$ & $\mathbf{N}$ & $\mathbf{\%}$ & $\mathbf{N}$ & $\mathbf{\%}$ & $\mathbf{N}$ & $\mathbf{\%}$ \\
\hline \hline 1 & Cairo & 21 & $15.3 \%$ & 22 & $16.1 \%$ & 20 & $14.7 \%$ & 63 & $24.4 \%$ \\
\hline 2 & Minya & 17 & $12.4 \%$ & 10 & $7.3 \%$ & 15 & $11 \%$ & 42 & $10.2 \%$ \\
\hline 3 & Dakahlia & 45 & $32.8 \%$ & 51 & $37.5 \%$ & 44 & $32.3 \%$ & 140 & $34.2 \%$ \\
\hline 4 & Damietta & 33 & $24 \%$ & 43 & $25 \%$ & 34 & $25 \%$ & 101 & $24.9 \%$ \\
\hline 5 & Alexandria & 24 & $17.1 \%$ & 19 & $13.9 \%$ & 20 & $15 \%$ & 63 & $15.4 \%$ \\
\hline \multicolumn{2}{c|}{ Total } & 140 & $34.2 \%$ & 136 & $33.2 \%$ & 133 & $32.5 \%$ & 409 & $100 \%$ \\
\hline \hline
\end{tabular}

\section{Data collection tools:}

"Basic Data" form for the research sample. Appendix (1)

1. "Product Packaging Policies Questionnaire " (prepared by the researcher), Appendix (2)

2. "Promotional Mix for Packaging Questionnaire ", (prepared by the researcher), Appendix (3)

- Basic Data form for research sample: It included the following data: name, age, income level.

- The product packaging policy form, which includes three axes, namely the quality of the cover, the shape and design of the packaging, and the social and environmental considerations of the packaging in its final form.

- The promotional mix form for packaging, which includes four axes, namely advertising, sales promotion, public relations, and personal selling in its final form.

- In the light of research concepts and terms, and within the framework of the procedural concept and previous studies, their response is determined according to the five-year estimate (strongly agree - agree - sometimes - disagree - strongly disagree) on a continuous scale (1 - $2-3-4-5)$ for the phrases.

\section{Statistical coefficients for the questionnaire:}

First: Calculating the honesty coefficient: 


\section{1- The validity of the arbitrators:}

The researcher relied on the honesty of the experts in order to determine the suitability of the phrases and axes of The product packaging policy questionnaire and The promotional mix form for packaging questionnaire, as some of the phrases were deleted, modified and added based on expert opinions.

\section{2- Truthfulness of internal consistency:}

To verify the suitability of the questionnaire expressions, the researcher applied the questionnaire to a survey sample of (50) from the consumers of sports products for commercial companies in the sports market in the Egyptian Arabic Republic, appointed by the research. The researcher used the validity of the internal consistency to calculate the validity of the axes and phrases of the questionnaire by finding the correlation coefficient between the phrases and their axes.

It was found that there was a statistically significant relationship at the level of significance $(0.01),(0.05)$ between the two product packaging policy questionnaires, and the promotional mix of packaging and their expressions, where the calculated value of $(\mathrm{R})$ was greater than the tabular in all terms, and thus can be based on the sincerity of the internal consistency between The axes and phrases of both questionnaires and the degree of the axis to which it belongs.

\section{Second: Calculation of the Reliability factor:}

The researcher used the Alpha Cronbach coefficient and the indication of internal consistency, to calculate the coefficient of stability of the axes of the questionnaire, where the researcher applied the questionnaire to a survey sample consisting of (50) consumers of sports products for commercial companies in the sports market in the Egyptian Arabic Republic.

The stability coefficient was calculated for the axes of the two questionnaires, as the consistency coefficient of Alfa Kronbach (0.865) for the questionnaire of product packaging policies, and the stability of the Alfa Kronbach coefficient (0.906) for the questionnaire of the promotional mix of packaging, and the internal consistency coefficient for each axis D, indicating the high coefficient of stability of the axes of the two questionnaires.

\section{Discussion and interpretation of statistical significance: First: Descriptive results of the research sample:}

The descriptive results showed that the calculated value of $(\mathrm{Ca} 2)$ is greater than the tabular (9.49), for all terms of the product packaging policy 
questionnaire, where the calculated value of $(\mathrm{Ca} 2)$ ranged between $(25.02$ : 270.81), which shows the presence of statistically significant differences in all terms.

Also, the phrases related to the promotional mix questionnaire for packaging, where the calculated value of $(\mathrm{Ca} 2)$ ranged between $(25.72$ : 191.45), which shows the presence of statistically significant differences in all terms.

Second: The results of the basic research sample in light of the research hypotheses:

1. There is a statistically significant correlation between the product packaging policies and its axes, the promotional mix of sports commercial companies and its axes.

It is clear from Table (2), Appendix (4) that there is a positive correlation relationship statistically significant at the level $(0,01)$ between the product packaging policies with their axes and the promotional mix of packaging, and the results of this study agreed with the study of both (Al-Amoush, 2010), (Ibn Mansour, 2017 ) In that good packaging plays an essential role in achieving competitive advantages for companies in the government and private sectors and one of the most important competitive advantages is the development of the use of the promotional mix for institutions and thus increasing sales and adjusting the intention of purchase and its behavior for the consumer of products in general, The researcher believes that the greater the interest of commercial institutions in the sports market in the quality of the cover and the continuous development of the cover design and taking into account environmental changes, customs and social traditions, a positive impact on advertising, public relations, personal selling and sales activation in sports institutions and thus achieve the first assumption entirely.

2. There are statistically significant differences between the averages of the research sample degrees in each of the product packaging policies and its axes, the promotional mix of sports commercial companies and its axes. By (age).

It is clear from Table (3), Appendix (5) there is a negative correlation relationship statistically significant at the level of significance (0.05) between the axis of the shape and design of the cover and the age, the axis of sales activation and the income level of the research sample, and these results are consistent with the results of a study (KJO, 2005) in that considerations Packaging works to build a mental image faster with older consumers, that recreational practices among members of society are greatly influenced by various factors of cultural change. This can be explained by the large difference in consumer interests in the shape and design of the packaging according to the difference in ages, due to the interest of the younger consumers in the shape of the cover more than 
others, and there is a difference in stimulating sales according to the level of income, because consumers with greater income are more buying than less income. Thus, the second assumption was partially achieved.

3. There are statistically significant differences between the averages of the research sample degrees in each of the product packaging policies and its axes, the promotional mix of sports commercial companies and its axes. By (age).

It is clear from Table (4), Appendix (6) that there are statistically significant differences at the level of significance (0.05), between the mean scores of the research sample in the axis of advertising in favor of the age group (from 20-30 years), and the results of this study agree with a study (Samahy, 2016) with the effect of The visual and informational factors of packaging on the consumer's purchasing decision, due to the effect of the age factor in favor of the younger age group in sports commercials, given that they are more interested in and searching for ads, whether traditional or electronic, and more affected by them. Thus, the third hypothesis was partially achieved.

4. There is a statistically significant difference between the degrees of the research sample in all product packaging policies and its axes, the promotional mix of sports commercial companies and its axes. According to (income level).

It is clear from Table (5), Appendix (7) that there is no discrepancy between the degrees of the research sample in the questionnaire of product packaging policies, and the questionnaire of the promotional mix of packaging, according to the level of income, due to the interest of all members of the sample in the quality and shape of the packaging and its design and influencing advertising of all kinds, and thus the fourth hypothesis did not achieve entirely.

\section{Research results and recommendations:}

\section{First: Descriptive research results:}

The descriptive results showed that the calculated value of $(\mathrm{Ca} 2)$ is greater than the tabular (9.49), for all phrases of the two questionnaires, where the calculated value of (Ca2) ranged between (25.02: 270.81), which shows the presence of statistically significant differences in all phrases.

\section{Second: Results in light of research hypotheses:}

- There is a negative correlation between the product packaging policies and the improvement of the promotional mix in the commercial enterprises exhibiting in the sports field.

- The mean of the responses of the research sample in the advertisement on the cover of sports products for the age group (20-30 years) varies. 
- Similarity of the responses of the research sample according to the age factor in the interest in the quality of the cover.

- The convergence of levels of the high-income research sample and others in personal selling.

- Convergence of the research sample in product packaging policies, and the promotional mix of packaging, depending on the level of income.

\section{Third: Research Recommendations:}

Based on the findings of the research results, and in light of the research hypotheses, the researcher provides these recommendations to the commercial companies exhibiting in the sports market in the Arab Republic of Egypt As follows:

- Developing the shape and design of sports product packaging, by:

- Attention to choose attractive attractive colors.

- Put pictures of famous athletes on the back of the cover.

- The necessity of creating a packaging form for sports products.

- Pay attention to designs with simple engineering dimensions.

- Paying attention to social and environmental considerations when designing, through:

- Packaging products using environmentally friendly materials.

- Convenience of the cover for health and preventive conditions.

- To be acceptable to society and to take into account living habits.

- The need to use the image and logos that suit the social environment.

- Product packaging works in an attractive and elegant manner in the success of corporate advertising campaigns.

- The packaging should contain the components that make up the product, weight, date of production, company name and country of origin.

- Paying attention to the way the product is displayed, especially how similar products are displayed in the adjacent shelves.

- Work to ensure that good packaging paints a positive image for the producing company.

\section{List of references:}

1- (The) Packaging Federation (2004), Packaging's Place in Society. Resource Efficiency of Packaging in the Supply Chain for Fast Moving Consumer Goods, The Packaging Federation, London.

2- Al-Smadi, Ziyad, 2010 AD: The role of packaging in achieving competitive advantage from the perspective of employees of 
agricultural marketing companies in the Central Amman Market: a field study, an unpublished Master Thesis, College of Business and Finance, Al-Bayt University, Jordan.

3- Banks, S. (1950), "The measurement of the effect of a new packaging material upon preference and sales", Journal of Business, Vol. 23, pp. 71-80.

4- Bo Rundh ,(2005): The multi-faceted dimension of packaging: Marketing logistic or marketing tool?, ISSN: 0007-070X, Publication date: 1 September

5- Bo Rundh,(2009): Packaging design: creating competitive advantage with product packaging, British Food Journal, ISSN: 0007-070X,Publication date: 5 September

6- Bone, P. and Corey, R.J. (2000), "Packaging ethics: perceptual differences among packaging professionals, brand managers, and ethically-interested consumers", Journal of Business Ethics, April, pp. 199-213.

7- Cervera Fantoni, A.L. (2003), Envase y embalaje. La venta silenciosa, ESIC, Madrid.

8- Garreston, J.A. and Burton, S. (2005), "The role of spoke characters as advertisement and package cues in integrated marketing communications", Journal of Marketing, Vol. 69, October, pp. 118-32.

9- George, J. (2005), “On paper, a world of opportunity”, Packaging World Magazine, April, p. 36.

10- Ibn Mansour, Ilham, 2017 AD: The effect of packaging on his intention to make a purchase decision with the consumer: a case study of consumers of the product brand "Rami", Journal of Studies, No. 52, March, University of Ammar Laghouat, Algeria.

11- Ivañez Gimeno, J.M. (2000), La gestión del diseño en la empresa, McGraw-Hill, Madrid.

12- Kajo, Atheer, 2005 AD: Packaging considerations and their role in building and enhancing mental status: an analytical study of the opinions of a sample of consumers of dairy products in the city of Mosul, an unpublished Master Thesis, College of Administration and Economics, University of Mosul, Iraq.

13- Lee, S.G. and Lye, S.W. (2003), "Design for manual packaging", International Journal of Physical Distribution \& Logistics Management, Vol. 33 No. 2, pp. 163-89.

14- McNeal, J.U. and Ji, M.F. (2003), "Children's visual memory of packaging", Journal of Consumer Marketing, Vol. 20 No. 5, pp. 400-27. 
15- Olga Ampuero, Natalia Vila (2006): Consumer perceptions of product packaging, Journal of Consumer Marketing, ISSN: 0736-3761, Publication date: 1 February

16- Packforsk (2001), Packaging

and

the

Environment, Packforsk, Kista,

available

at: www.packforsk.se/pdf-files/facts (accessed 21 October 2004).

17- Prendergast, G. and Pitt, L. (1996), “Packaging, marketing logistics and the environment: are there tradeoffs?", International Journal of Physical Distribution \& Logistics Management, Vol. 26 No. 6, pp. 60-72.

18- Raghubir, P. and Greenleaf, E.A. (2006), "Ratios in Proportion: what should the shape of the package be?", Journal of Marketing, Vol. 70, April, pp. 95-107.

19- Samahi, Ahmed, 2016 AD: The effect of visual and informational factors of packaging on the consumer's purchasing decision, Dirasat Magazine, No. 42, May, Amar Al-Agwat University, Algeria.

20- Underwood, R.L. (2003), "The communicative power of product packaging: creating brand identity via lived and mediated experience", Journal of Marketing Theory and Practice, Winter, pp. 62-76.

21- Underwood, R.L., Klein, N.M. and Burke, R.R. (2001), "Packaging communication: attentional effects of product imagery", Journal of Product \& Brand Management, Vol. 10 No. 7, pp. 403-22.

22- Vidales Giovannetti, M.D. (1995), El mundo del envase. Manual para el diseño y producción de envases y embalajes, Gustavo Gili, Mexico City, p. 90.

Appendix (1)

Basic data form for the research sample

1- Name (optional ):

2-Age: ( ) From 20: 30 year

( ) From 30: 40 year.

3-Income level: ( ) High ( ) Medium ( ) Low. 
Appendix (2)

Sports product packaging policies (Independent variable)

\begin{tabular}{c|c|c|c|c|c|c}
\hline \hline $\mathbf{N}$ & Phrase & $\begin{array}{c}\text { Strong } \\
\text { Agree }\end{array}$ & Agree & Neutral & Disagree & $\begin{array}{c}\text { Strong } \\
\text { Disagree }\end{array}$ \\
\hline \hline
\end{tabular}

Frist Axis : 


\begin{tabular}{|c|c|c|c|c|c|c|}
\hline $\mathbf{N}$ & Phrase & $\begin{array}{l}\text { Strong } \\
\text { Agree }\end{array}$ & Agree & Neutral & Disagree & $\begin{array}{c}\text { Strong } \\
\text { Disagree }\end{array}$ \\
\hline \multicolumn{7}{|c|}{ Cover quality } \\
\hline 1 & $\begin{array}{l}\text { Good packaging reduces } \\
\text { damage and damage to } \\
\text { sports products. }\end{array}$ & & & & & \\
\hline 2 & $\begin{array}{l}\text { The quality and consistency } \\
\text { of the packing material in } \\
\text { terms of shape and color } \\
\text { give a positive impression } \\
\text { of the commodity. }\end{array}$ & & & & & \\
\hline 3 & $\begin{array}{l}\text { The company uses modern } \\
\text { techniques in designing the } \\
\text { cover to face external } \\
\text { factors. }\end{array}$ & & & & & \\
\hline 4 & $\begin{array}{l}\text { Good packaging beers, } \\
\text { product features and } \\
\text { specifications. }\end{array}$ & & & & & \\
\hline 5 & $\begin{array}{l}\text { The size of the wrapper } \\
\text { reflects the amount inside. }\end{array}$ & & & & & \\
\hline 6 & $\begin{array}{l}\text { A good coating helps } \\
\text { protect the properties of the } \\
\text { product. }\end{array}$ & & & & & \\
\hline 7 & $\begin{array}{l}\text { Maintains product } \\
\text { consistency and quality. }\end{array}$ & & & & & \\
\hline 8 & $\begin{array}{l}\text { I prefer good packaging } \\
\text { with a similar good with } \\
\text { poor packaging. }\end{array}$ & & & & & \\
\hline
\end{tabular}

The Second Axis:

Cover shape and design

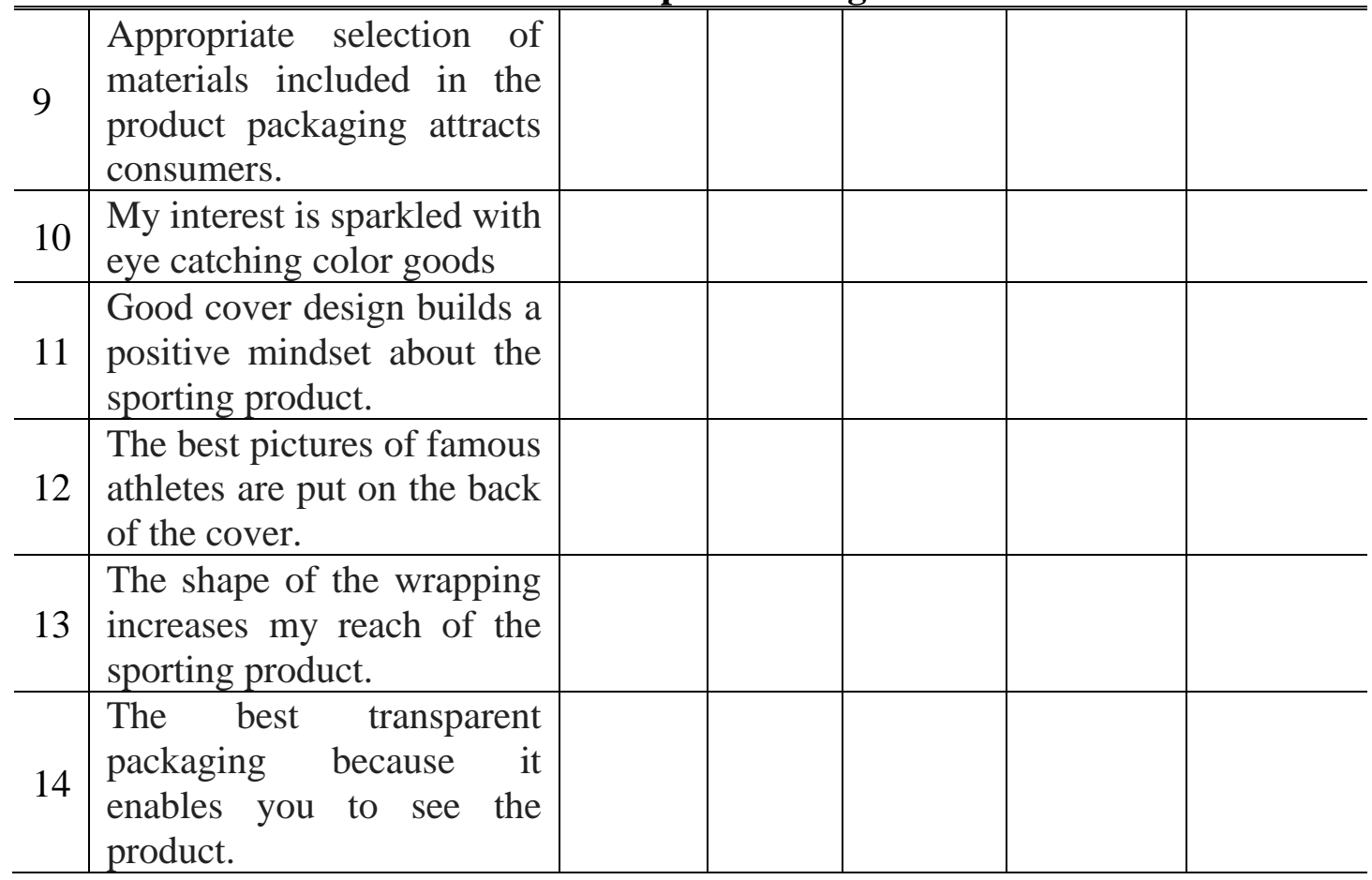




\begin{tabular}{|c|c|c|c|c|c|c|}
\hline $\mathbf{N}$ & Phrase & $\begin{array}{l}\text { Strong } \\
\text { Agree }\end{array}$ & Agree & Neutral & Disagree & $\begin{array}{c}\text { Strong } \\
\text { Disagree }\end{array}$ \\
\hline 15 & $\begin{array}{l}\text { 1 love sports products with } \\
\text { innovative packaging }\end{array}$ & & & & & \\
\hline 16 & $\begin{array}{l}\text { Smooth and attractive } \\
\text { packaging helps to attract } \\
\text { consumers of the competing } \\
\text { brand. }\end{array}$ & & & & & \\
\hline 17 & $\begin{array}{l}\text { The best shapes with simple } \\
\text { geometric dimensions. }\end{array}$ & & & & & \\
\hline
\end{tabular}

The Third Axis:

Social and environmental considerations

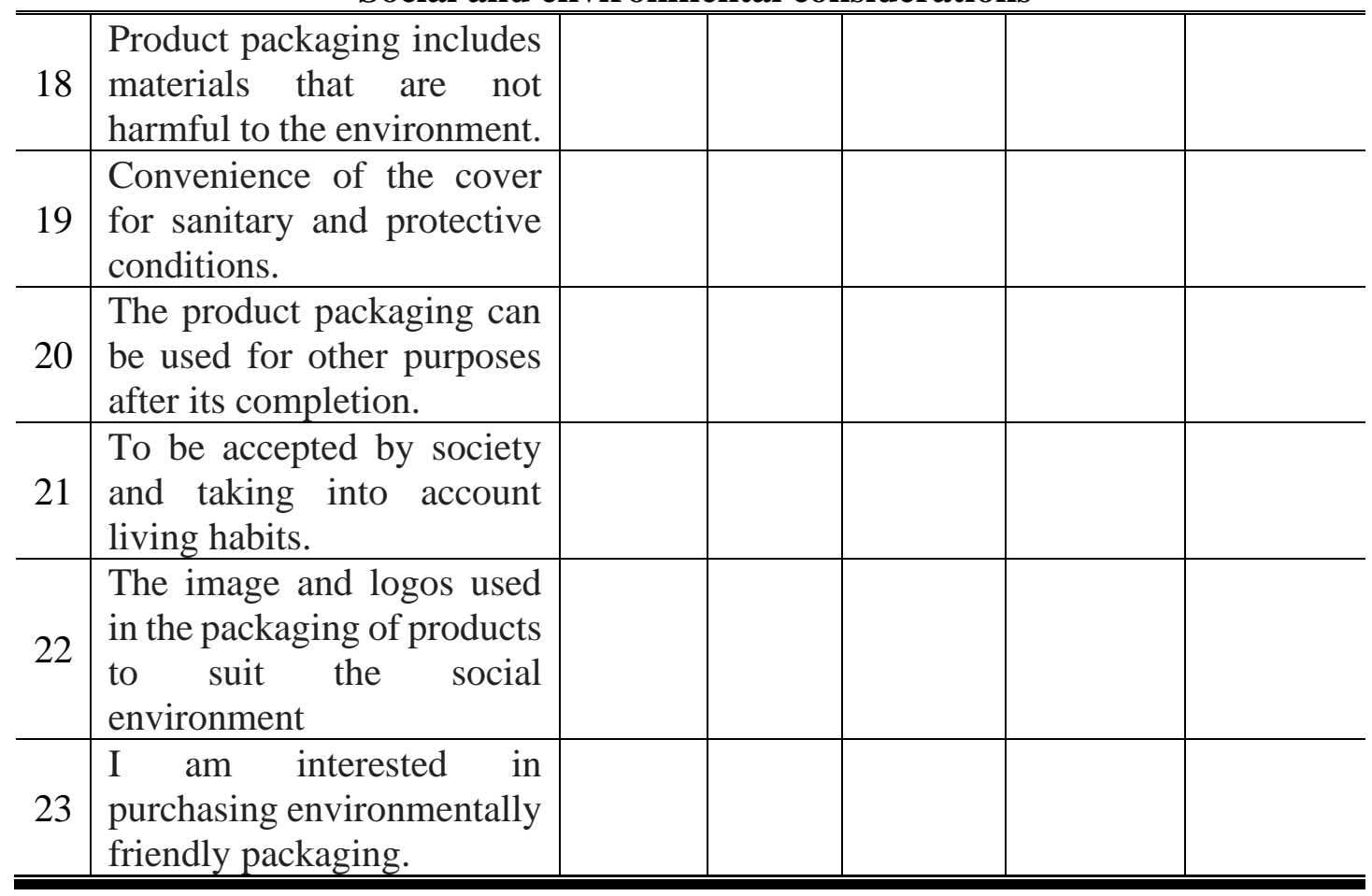

Appendix (3) 
The promotional mix for commercial companies

(Dependent variable)

\begin{tabular}{|c|c|c|c|c|c|c|}
\hline $\mathbf{N}$ & Phrase & $\begin{array}{l}\text { Strong } \\
\text { Agree } \\
\end{array}$ & Agree & Neutral & Disagree & $\begin{array}{c}\text { Strong } \\
\text { Disagree } \\
\end{array}$ \\
\hline \multicolumn{7}{|c|}{$\begin{array}{l}\text { Frist Axis : } \\
\text { Advertising }\end{array}$} \\
\hline 24 & $\begin{array}{l}\text { I affected by the advertising } \\
\text { message on the cover. }\end{array}$ & & & & & \\
\hline 25 & $\begin{array}{l}\text { I trust the information on } \\
\text { the cover. }\end{array}$ & & & & & \\
\hline 26 & $\begin{array}{l}\text { The product ad is mainly } \\
\text { cover dependent. }\end{array}$ & & & & & \\
\hline 27 & $\begin{array}{l}\text { Attractively and elegantly } \\
\text { wrapped the product in its } \\
\text { advertising campaigns. }\end{array}$ & & & & & \\
\hline 28 & $\begin{array}{l}\text { Sufficient information is } \\
\text { available on the cover that } \\
\text { interests the consumer and } \\
\text { arouses his desire to } \\
\text { purchase. }\end{array}$ & & & & & \\
\hline 29 & $\begin{array}{l}\text { The packaging contains the } \\
\text { components that make up } \\
\text { the product, weight, date of } \\
\text { production, company name } \\
\text { and country of origin }\end{array}$ & & & & & \\
\hline 30 & $\begin{array}{l}\text { Bar codes help me quickly } \\
\text { to identify the country of } \\
\text { origin of the product }\end{array}$ & & & & & \\
\hline
\end{tabular}

The Second Axis:

Stimulate sales

\begin{tabular}{l|l|l|l|l|l}
\hline \hline 31 & $\begin{array}{l}\text { The package size affects the } \\
\text { purchase intent of the } \\
\text { sporting product. }\end{array}$ & & & & \\
\hline 32 & $\begin{array}{l}\text { The country of manufacture } \\
\text { of the mark affects the } \\
\text { purchasing decision. }\end{array}$ & & & & \\
\hline 33 & $\begin{array}{l}\text { Good packaging helps me } \\
\text { easily identify the product } \\
\text { among alternative products. }\end{array}$ & $\begin{array}{l}\text { The cover takes into } \\
\text { account the purchasing } \\
\text { habits of luxury, comfort } \\
\text { and ease of use. }\end{array}$ & & & \\
\hline 35 & $\begin{array}{l}\text { The product brand affects } \\
\text { his buying intent. }\end{array}$ & & & \\
\hline 36 & $\begin{array}{l}\text { Pay attention to how the } \\
\text { product is displayed, }\end{array}$ & & & & \\
\hline \hline
\end{tabular}




\begin{tabular}{c|c|c|c|c|c|c}
\hline \hline $\mathbf{N}$ & Phrase & $\begin{array}{c}\text { Strong } \\
\text { Agree }\end{array}$ & Agree & Neutral & Disagree & $\begin{array}{c}\text { Strong } \\
\text { Disagree }\end{array}$ \\
\hline \hline & $\begin{array}{l}\text { especially how similar } \\
\text { products are displayed in } \\
\text { adjacent shelves. }\end{array}$ & & & & \\
\hline \hline
\end{tabular}

The Third Axis:

Public relations

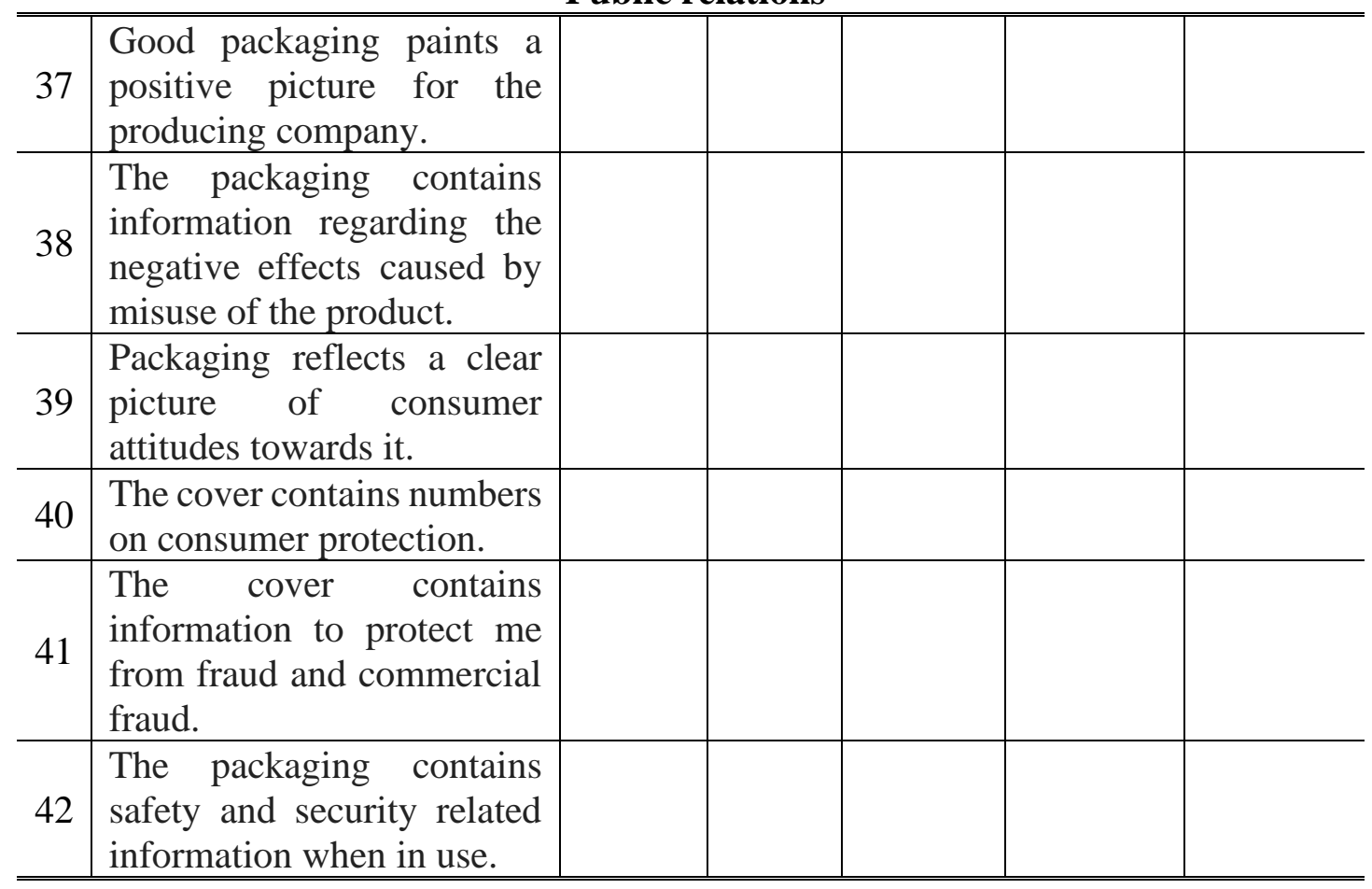

\section{The Fourth Axis:}

Personal selling

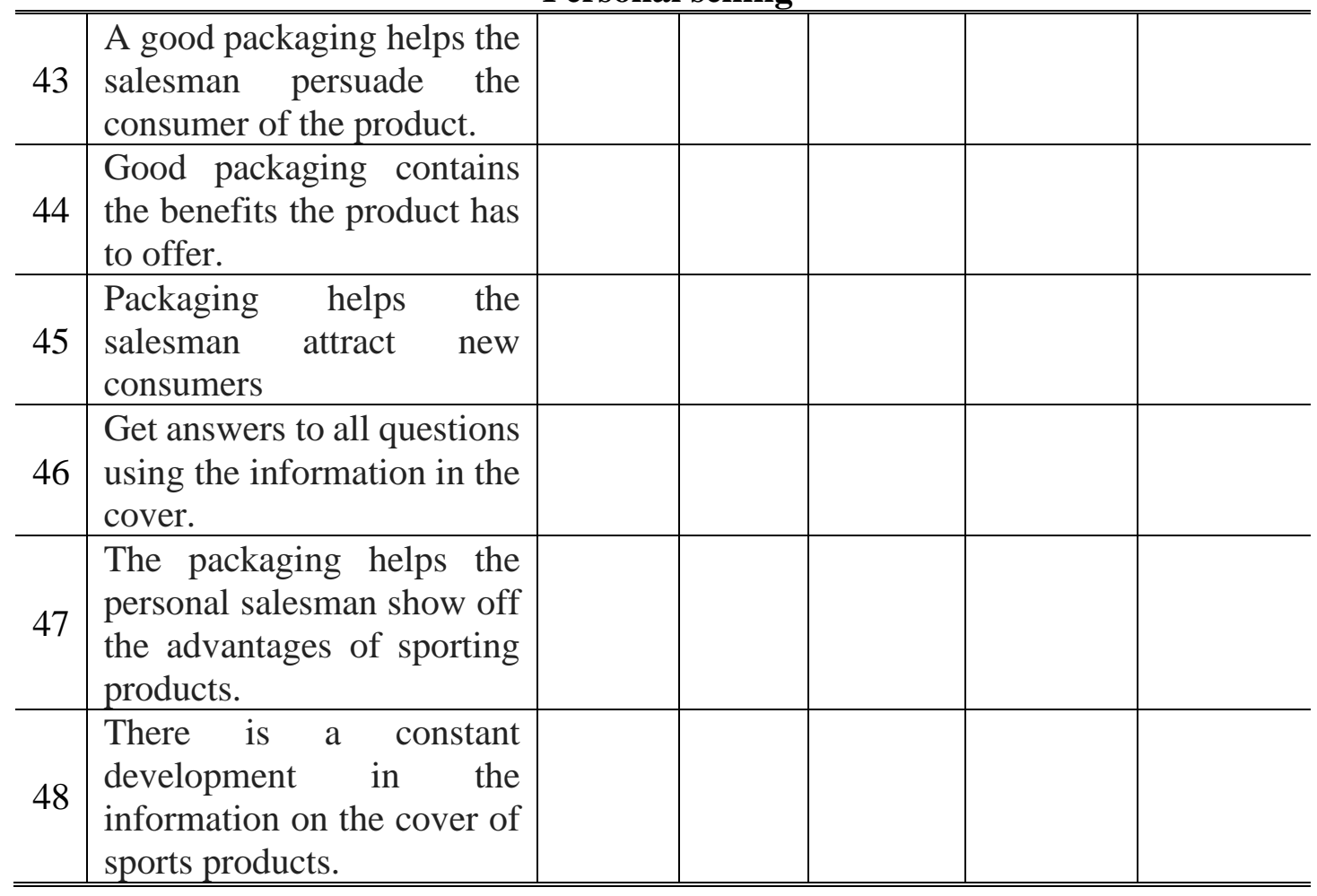




\section{Appendix (4)}

Table (2) Correlation coefficients between product packaging policies with its axes and the promotional mix of packaging with its axes $(n=409)$

\begin{tabular}{|c|c|c|c|c|c|c|}
\hline \multirow{2}{*}{\multicolumn{2}{|c|}{ Variables }} & \multicolumn{5}{|c|}{ Promotional mix for packaging } \\
\hline & & Advertising & $\begin{array}{c}\text { Stimulate } \\
\text { sales }\end{array}$ & $\begin{array}{c}\text { Public } \\
\text { relations }\end{array}$ & $\begin{array}{c}\text { Personal } \\
\text { selling }\end{array}$ & $\begin{array}{c}\text { Total } \\
\text { Degree }\end{array}$ \\
\hline \multirow{4}{*}{ 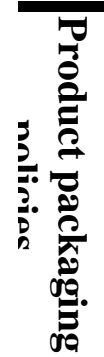 } & Cover quality & $0.450 * *$ & $0.413 * *$ & $0.382 * *$ & $0.486 * *$ & $0.511 * *$ \\
\hline & $\begin{array}{l}\text { Cover shape } \\
\text { and design }\end{array}$ & $0.511 * *$ & $0.581 * *$ & $0.474 * *$ & $0.623 * *$ & $0.650 * *$ \\
\hline & $\begin{array}{c}\text { Social and } \\
\text { environmental } \\
\text { considerations }\end{array}$ & $0.473 * *$ & $0.507 * *$ & $0.470 * *$ & $0.498 * *$ & $0.576 * *$ \\
\hline & Total Degree & $0.558 * *$ & $0.585 * *$ & $0.511 * *$ & $0.632 * *$ & $0.677 * *$ \\
\hline
\end{tabular}

\section{Appendix (5)}

Table (3) Correlation coefficients between product packaging policies with its axis and the promotional mix of packaging with its axis and some variables of the demographic study $(n=409)$

\begin{tabular}{|c|c|c|c|}
\hline & Variables & Age & Income level \\
\hline \multirow{4}{*}{ 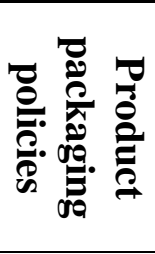 } & Cover quality & -0.013 & 0.021 \\
\hline & Cover shape and design & $-0.121 *$ & -0.029 \\
\hline & $\begin{array}{c}\text { Social and environmental } \\
\text { considerations }\end{array}$ & 0.017 & -0.006 \\
\hline & $\begin{array}{c}\text { Total Degree } \\
\end{array}$ & -0.027 & -0.007 \\
\hline \multirow{5}{*}{ 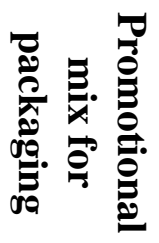 } & Advertising & 0.001 & -0.005 \\
\hline & Stimulate sales & -0.068 & $-0.109 *$ \\
\hline & Public relations & -0.057 & -0.068 \\
\hline & Personal selling & -0.096 & -0.025 \\
\hline & Total Degree & -0.67 & -0.037 \\
\hline
\end{tabular}

(**) significant at the level (0.01)

(*) significant at the level (0.05) 


\section{Appendix (6)}

Table (4) Differences between the averages of the sample degrees of research in the policies of product packaging with its axis and the promotional mix of packaging with its axis according to age $(n=409)$

\begin{tabular}{|c|c|c|c|c|c|c|c|}
\hline & Axes & Age & Mean & $\begin{array}{c}\text { Std. } \\
\text { deviation }\end{array}$ & $\begin{array}{c}\text { Mean } \\
\text { Differences }\end{array}$ & $(\mathbf{t})$ & Sig \\
\hline \multirow{8}{*}{ 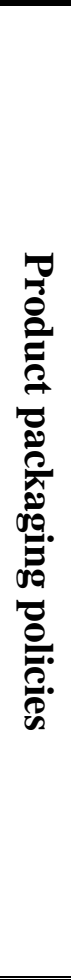 } & \multirow{2}{*}{ Cover quality } & $\begin{array}{c}20: 30 \\
(N= \\
213)\end{array}$ & 21.08 & 6.31 & \multirow{2}{*}{0.1657} & \multirow{2}{*}{0.27} & \multirow{2}{*}{$\begin{array}{l}\text { No. } \\
\text { Sig }\end{array}$} \\
\hline & & $\begin{array}{c}30: 40 \\
(\mathrm{~N}= \\
196)\end{array}$ & 20.29 & 5.98 & & & \\
\hline & \multirow{2}{*}{$\begin{array}{l}\text { Cover shape } \\
\text { and design }\end{array}$} & $\begin{array}{c}20: 30 \\
(\mathrm{~N}= \\
213)\end{array}$ & 25.43 & 6.98 & \multirow{2}{*}{0.7737} & \multirow{2}{*}{1.12} & \multirow{2}{*}{$\begin{array}{l}\text { No. } \\
\text { Sig }\end{array}$} \\
\hline & & $\begin{array}{c}\text { 30: } 40 \\
(\mathrm{~N}= \\
196)\end{array}$ & 24.65 & 6.94 & & & \\
\hline & \multirow{2}{*}{$\begin{array}{c}\text { Social and } \\
\text { environmental } \\
\text { considerations }\end{array}$} & $\begin{array}{c}20: 30 \\
(N= \\
213)\end{array}$ & 15.93 & 4.28 & \multirow{2}{*}{-0.1422} & \multirow{2}{*}{-0.34} & \multirow{2}{*}{$\begin{array}{l}\text { No. } \\
\text { Sig }\end{array}$} \\
\hline & & $\begin{array}{c}30: 40 \\
(\mathrm{~N}= \\
196)\end{array}$ & 16.07 & 4.10 & & & \\
\hline & \multirow{2}{*}{ Total Degree } & $\begin{array}{c}20: 30 \\
(\mathrm{~N}= \\
213)\end{array}$ & 62.45 & 15.09 & \multirow{2}{*}{0.7972} & \multirow{2}{*}{0.054} & \multirow{2}{*}{$\begin{array}{l}\text { No. } \\
\text { Sig }\end{array}$} \\
\hline & & $\begin{array}{c}30: 40 \\
(\mathrm{~N}= \\
196)\end{array}$ & 61.65 & 14.70 & & & \\
\hline \multirow{9}{*}{ 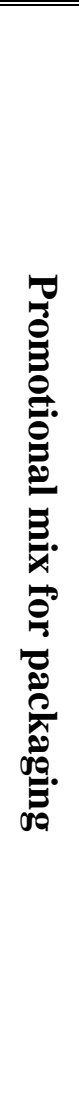 } & \multirow{2}{*}{ Advertising } & $\begin{array}{c}20: 30 \\
(N= \\
213)\end{array}$ & 17.11 & 4.22 & \multirow{2}{*}{0.0089} & \multirow{2}{*}{0.02} & \multirow{2}{*}{$\begin{array}{l}\text { Sig at } \\
(0,05) \\
30: 40\end{array}$} \\
\hline & & $\begin{array}{c}30: 40 \\
(\mathrm{~N}= \\
196)\end{array}$ & 17.10 & 4.79 & & & \\
\hline & \multirow{2}{*}{$\begin{array}{l}\text { Stimulate } \\
\text { sales }\end{array}$} & $\begin{array}{c}20: 30 \\
(N= \\
213)\end{array}$ & 17.00 & 5.74 & \multirow{2}{*}{0.7598} & \multirow{2}{*}{1.37} & \multirow{2}{*}{$\begin{array}{l}\text { No. } \\
\text { Sig }\end{array}$} \\
\hline & & $\begin{array}{c}30: 40 \\
(\mathrm{~N}= \\
196)\end{array}$ & 16.24 & 5.44 & & & \\
\hline & \multirow{2}{*}{$\begin{array}{l}\text { Public } \\
\text { relations }\end{array}$} & $\begin{array}{c}20: 30 \\
(N= \\
213)\end{array}$ & 14.25 & 4.41 & \multirow{2}{*}{0.4929} & \multirow{2}{*}{1.14} & \multirow{2}{*}{$\begin{array}{l}\text { No. } \\
\text { Sig }\end{array}$} \\
\hline & & $\begin{array}{c}30: 40 \\
(\mathrm{~N}= \\
196)\end{array}$ & 13.76 & 4.26 & & & \\
\hline & \multirow{2}{*}{$\begin{array}{l}\text { Personal } \\
\text { selling }\end{array}$} & $\begin{array}{c}20: 30 \\
(N= \\
213)\end{array}$ & 16.02 & 5.08 & \multirow{2}{*}{0.9414} & \multirow{2}{*}{1.94} & \multirow{2}{*}{$\begin{array}{l}\text { No. } \\
\text { Sig }\end{array}$} \\
\hline & & $\begin{array}{c}\text { 30: } 40 \\
(\mathrm{~N}= \\
196) \\
\end{array}$ & 15.08 & 4.65 & & & \\
\hline & Total Degree & $\begin{array}{c}20: 30 \\
(N= \\
213)\end{array}$ & 64.39 & 16.92 & 2.1851 & 1.34 & $\begin{array}{l}\text { No. } \\
\text { Sig }\end{array}$ \\
\hline
\end{tabular}




\begin{tabular}{l|c|c|c|c|c|c|c}
\hline \hline Axes & Age & Mean & $\begin{array}{c}\text { Std. } \\
\text { deviation }\end{array}$ & $\begin{array}{c}\text { Mean } \\
\text { Differences }\end{array}$ & (t) & Sig \\
\hline \hline & & $\begin{array}{c}30: 40 \\
(\mathrm{~N}= \\
196)\end{array}$ & 62.20 & 15.82 & & & \\
\hline \hline
\end{tabular}

\section{Appendix (7)}

Table (5) Differences between the study sample in each of the product packaging policies in its hubs and the promotional mix of packaging in its hubs according to the income level $(n=409)$

\begin{tabular}{|c|c|c|c|c|c|c|c|}
\hline Questionnaire & Variables & $\begin{array}{l}\text { Contrast } \\
\text { Source }\end{array}$ & $\begin{array}{l}\text { Sum Of } \\
\text { Square }\end{array}$ & Df & $\begin{array}{c}\text { Mean } \\
\text { Square }\end{array}$ & $\mathbf{F}$ & Sig \\
\hline \multirow{4}{*}{ 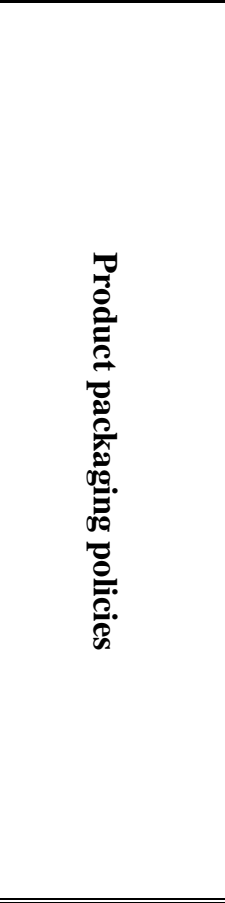 } & Cover quality & $\begin{array}{c}\text { Between } \\
\text { Groups } \\
\text { Within } \\
\text { Groups } \\
\text { Total }\end{array}$ & $\begin{array}{c}19.42 \\
15422.53 \\
15441.96\end{array}$ & $\begin{array}{c}2 \\
406 \\
408\end{array}$ & $\begin{array}{c}9.71 \\
37.98\end{array}$ & 0.25 & $\begin{array}{l}\text { No. } \\
\text { Sig }\end{array}$ \\
\hline & $\begin{array}{l}\text { Cover shape } \\
\text { and design }\end{array}$ & $\begin{array}{c}\text { Between } \\
\text { Groups } \\
\text { Within } \\
\text { Groups } \\
\text { Total } \\
\end{array}$ & $\begin{array}{c}21.60 \\
19707.86 \\
19729.47\end{array}$ & $\begin{array}{c}2 \\
406 \\
408\end{array}$ & $\begin{array}{l}10.80 \\
48.54\end{array}$ & 0.22 & $\begin{array}{l}\text { No. } \\
\text { Sig }\end{array}$ \\
\hline & $\begin{array}{c}\text { Social and } \\
\text { environmental } \\
\text { considerations }\end{array}$ & $\begin{array}{c}\text { Between } \\
\text { Groups } \\
\text { Within } \\
\text { Groups } \\
\text { Total }\end{array}$ & $\begin{array}{c}1.41 \\
7173.58 \\
7174.99\end{array}$ & $\begin{array}{c}2 \\
406 \\
408\end{array}$ & $\begin{array}{c}0.70 \\
17.66\end{array}$ & 0.40 & $\begin{array}{l}\text { No. } \\
\text { Sig }\end{array}$ \\
\hline & $\begin{array}{c}\text { Total } \\
\text { Degree }\end{array}$ & $\begin{array}{c}\text { Between } \\
\text { Groups } \\
\text { Within } \\
\text { Groups } \\
\text { Total }\end{array}$ & $\begin{array}{c}4.12 \\
90489.67 \\
90493.80\end{array}$ & $\begin{array}{c}2 \\
406 \\
408\end{array}$ & $\begin{array}{c}2.06 \\
222.88\end{array}$ & 0.009 & $\begin{array}{l}\text { No. } \\
\text { Sig }\end{array}$ \\
\hline \multirow{2}{*}{ 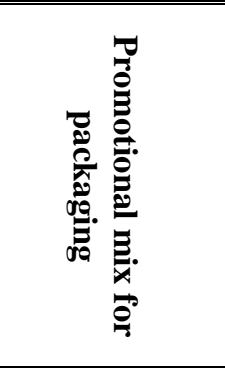 } & Advertising & $\begin{array}{c}\text { Between } \\
\text { Groups } \\
\text { Within } \\
\text { Groups } \\
\text { Total }\end{array}$ & $\begin{array}{c}1.68 \\
8355.57 \\
8357.26\end{array}$ & $\begin{array}{c}2 \\
406 \\
408\end{array}$ & $\begin{array}{c}0.84 \\
20.58\end{array}$ & 0.04 & $\begin{array}{l}\text { No. } \\
\text { Sig }\end{array}$ \\
\hline & $\begin{array}{c}\text { Stimulate } \\
\text { sales }\end{array}$ & $\begin{array}{l}\text { Between } \\
\text { Groups } \\
\text { Within } \\
\text { Groups }\end{array}$ & $\begin{array}{c}11.08 \\
12819.08\end{array}$ & $\begin{array}{c}2 \\
406\end{array}$ & $\begin{array}{c}5.54 \\
31.57\end{array}$ & 0.17 & $\begin{array}{l}\text { No. } \\
\text { Sig }\end{array}$ \\
\hline
\end{tabular}




\begin{tabular}{|c|c|c|c|c|c|c|c|}
\hline Questionnaire & Variables & $\begin{array}{c}\text { Contrast } \\
\text { Source }\end{array}$ & $\begin{array}{l}\text { Sum of } \\
\text { Square }\end{array}$ & Df & $\begin{array}{c}\text { Mean } \\
\text { Square }\end{array}$ & $\mathbf{F}$ & Sig \\
\hline & & Total & 12830.16 & 408 & & & \\
\hline & $\begin{array}{l}\text { Public } \\
\text { relations }\end{array}$ & $\begin{array}{c}\text { Between } \\
\text { Groups } \\
\text { Within } \\
\text { Groups } \\
\text { Total }\end{array}$ & $\begin{array}{c}36.21 \\
7666.58 \\
7702.80\end{array}$ & $\begin{array}{c}2 \\
406 \\
408\end{array}$ & $\begin{array}{l}18.10 \\
18.88\end{array}$ & 0.95 & $\begin{array}{l}\text { No. } \\
\text { Sig }\end{array}$ \\
\hline & $\begin{array}{c}\text { Personal } \\
\text { selling }\end{array}$ & $\begin{array}{c}\text { Between } \\
\text { Groups } \\
\text { Within } \\
\text { Groups } \\
\text { Total }\end{array}$ & $\begin{array}{c}7.16 \\
9782.65 \\
9789.82\end{array}$ & $\begin{array}{c}2 \\
406 \\
408\end{array}$ & $\begin{array}{c}3.58 \\
24.09\end{array}$ & 0.14 & $\begin{array}{l}\text { No. } \\
\text { Sig }\end{array}$ \\
\hline & $\begin{array}{c}\text { Total } \\
\text { Degree }\end{array}$ & $\begin{array}{c}\text { Between } \\
\text { Groups } \\
\text { Within } \\
\text { Groups } \\
\text { Total }\end{array}$ & $\begin{array}{c}148.79 \\
109883.90 \\
110032.69\end{array}$ & $\begin{array}{c}2 \\
406 \\
408\end{array}$ & $\begin{array}{c}74.39 \\
270.65\end{array}$ & 0.27 & $\begin{array}{l}\text { No. } \\
\text { Sig }\end{array}$ \\
\hline
\end{tabular}

